\title{
Single and Multiple Sluicing in Persian
}

\author{
Saeedeh Shafiee Nahrkhalaji (Corresponding Author) \\ Department of English, School of Humanities, Islamic Azad University, Najafabad Branch, Isfahan, Iran \\ Email: s_shafiee@phu.iaun.ac.ir
}

Morteza Rashidi Ashjerdi
Department of Persian Language and Literature, School of Humanities, Islamic Azad University, Najafabad Branch,
Isfahan, Iran
Email: m_rashidi@phu.iaun.ac.ir

\begin{abstract}
This article discusses the syntax and LF properties of the phenomenon of sluicing as ellipsis of the sentential complement to an interrogative complementizer hosting a wh-phrase in Persian. The main purpose of this paper is to explore sluicing in Persian as a real wh-in-situe language that displays optional $w \boldsymbol{h}$ movement, with a special focus on multiple sluicing. Built on focus movement analysis rather than whmovement, we examined the movement-plus-deletion approach and the role of focus fronting in moving the remnant out of the deleted constituent in Persian sluicing to a position where it can be stranded. Finally, we also looked into possibility of non-interrogative sluicing and non-d-linked wh words and briefly put forward our proposition about wh the hell phrases in Persian.
\end{abstract}

Index Terms — single sluicing, multiple sluicing, wh-fronting, wh-movement, focus fronting

\section{THE PHENOMENON OF SLUiCING}

Sluicing, first explored by Ross (1969), is ellipsis of the sentential complement to an interrogative complementizer hosting a wh-phrase. Different parts of a sluicing construction are illustrated in 1 and 2:

1) Mary wrote something, but I do not know [ср what [тр Mary wrote]].

2) Ali ye chizi xarid, nemidunam [CP chi [тр Ali xarid]].

Ali one thing bought.3SG NEG. know.1SG what Ali bought.3SG

'Ali bought something, I don't know what.' Persian

The interrogative phrase <what $>$ is remnant. The deleted TP <Mary wrote> is the target. The TP <Mary wrote something > to which the target clause is identical is called antecedent. The constituent <something $>$ that corresponds to the remnant is correlate. The remnant and the target compromise the sluice. Similarly in Persian we have <chi $>$ as the remnant, <Ali xarid> as the target, <Ali ye chizi xarid> as the antecedent, <ye chizi> as the correlate and <chi Ali xarid $>$ as the sluice. Looking at these examples, sluicing in Persian seems to be identical on the surface to sluices in English.

Within structural approaches to the syntax of elliptical structures, there are two main lines of investigations:

1. One strand of research, presented by Lobeck (1995) and Ludlow (2005), posits a plethora of null elements (3.b) or a single null element (3.a) replaced by some operation of structure copying at some level of representation (LF-copy) or interpreted in some semantic or pragmatic component (null-anaphora) (3.c).

3) Mary ate something, but

a. I do not know [сР what [тP e]] (spell-out)

b. I do not know [CP what [TP $\left.\left.\mathrm{e}_{1} \mathrm{e}_{2} \mathrm{e}_{3}\right]\right]$

c. I do not know [cP what [TP Mary ate $\left.t_{3}\right]$ ]

2. The other line of investigations posits syntactic structure subject to some kind of deletion (FL-deletion). This approach ranges from the traditional theory of Ross to more recent proposal of E-feature by Merchant (2001). Lasnik (2005) reappraise Ross's analysis in a minimalist setting. Under this wh-movement + deletion approach, the syntax of an ellipsis site is just the same as the syntax of its non-elliptical counterpart, but subject to some kind of operation which leads to non-pronunciation.

Ross (1969) assumes that the wh-phrase has been moved from its usual position to the beginning of the clause, to Spec CP out of the missing TP. This operation which is triggered by the usual mechanism of wh-movement in questions is then followed by phonetic deletion of the rest of the clause. Merchant (2001) assumes that the ellipsis of TP or PF deletion is licensed by the presence of a triggering feature on a head called $\mathrm{E}$, rather being the result of a freely operating deletion which is also active in other elliptical constructions.

E localizes ellipsis identification and enables us to postulate "a global, late, well-formedness condition" imposed just on the structures containing ellipsis. The E-feature is the repository of syntactic, semantic and phonological information about the ellipsis. Just looking at (4.a), we can see that the original site of the moved wh phrase <what> is inside the 
unpronounced sentential node. There is no need to generate it in spec CP. C is the licensing head for sluicing and the [E] feature is added to the feature matrix of it as schematized in (4.b):

4) a. Something drove him crazy, but I don't know what.

b.

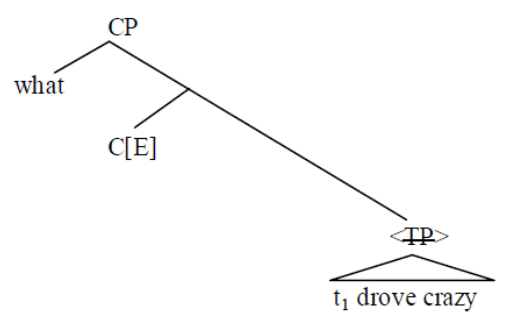

Structural approaches to ellipsis are based on connectivity effects, i.e. some part of the clause that contains the ellipsis shows connectivity to some unpronounced part. Merchant (2008) explores locality effects, the distribution of complementizers, of infinitivals and of predicate answer as a set of facts as evidence for unpronounced structure for ellipsis and some kind of data as the evidence against structure in ellipsis.

In the next section, two arguments will be discussed: 1 . The interrogative phrase like chi <what> does not raise to Spec CP and escapes deletion. 2. The interrogative phrase like chi <what> raises to the specifier of a focus projection (Toosarvandani, 2008).

\section{SLUICING IN PERSIAN}

Toosarvandani (2008) argues that sluices in Persian like English cannot be assimilated to stripping and due to a lot of restrictions on the pivot of a cleft do not hold of the remnant in a sluice; sluices cannot be derived from a cleft. We can think of two arguments for syntactic movement of the remnant in sluicing. The weak evidence for movement comes from the position of the remnant with respect to the verb (Merchant, 2001). In Persian with SOV word order, CP arguments of the verb occur to the right (5) and the remnant in a sluice can only occur to the right of the verb (6).

5) a. midunam [СР ke [TP Ali nemitune biyâd.]]

Know.1SG that Ali NEG.can come.3SG

'I know that Ali can't come.'

b. * [ $\mathrm{CP}$ ke [TP Ali nemitone biyâd]] midunam.

that Ali NEG.can come.3SG know.1SG

6) a. ali ye chizi goft vali nafahmidam chi.

Ali one thing said.3SG but NEG.understood.1SG what

'Ali said something, but I didn't understand what.'

b. *ali ye chizi goft vali chi nafahmidam.

Ali one thing said.3SG but what NEG.understood.1SG

The strong evidence for movement, according to Merchant (2001), can be discussed under the rubric of FORMIDENTITY-GENERALIZATIONS based on which "the remnant behave just like its non-elliptical." It should obey the usual constraints on movement if it undergoes movement to arrive at its position. Case-marking and preposition stranding are two form-identity-generalizations. Since Persian like English is not very strong in its case morphology, this evidence is not very helpful. However, the object marker $r a ̂$ that occurs on specific object DPs and realized as $o$ or ro in colloquial speech can be examined. As shown in (7), the presence of $r a ̂$ is obligatory, while in the corresponding sluice in (8) it is optional.

7) a. ki-o polis $\langle\mathrm{ki}-\mathrm{o}>$ dastgir kard?

Who-OBJ police arrested.\#SG

'Who did the police arrested?'

*b. ki polis < ki > dastgir kard?

Who.OBJ police arrested.\#SG

8) polis ye nafar-i-o dastgir kard vali nemidunam ki(o).

Police one person-IND-OB arrested.3SG but NEG.know.1SG who (OBJ)

'The police arrested someone, but I don't know who.'

The optionality of this presence cannot be considered as evidence against the movement-plus-deletion analysis of sluicing.

Preposition stranding generalization can be regarded as the strongest evidence for a movement + deletion account sluicing (Merchant, 2001). Boeckx (2006) uses this generalization as the crucial evidence for this fact that sluicing cannot repair anti-locality violations. In languages such as English which allow wh-phrase to strand a preposition under wh-movement, it is possible to omit the preposition of a PP correlate of a DP remnant (9). (Examples taken from Merchant 2001). In Persian as a pied-piping language, retention of the preposition under sluicing is obligatory (10).

9) a. Peter was talking to someone, but I don't know (with) who. 
b. Who was he talking with?

10) a. <bâ ki> Ali bâ ki harf mizad?

Ali with who speech hit.3SG

'Who was Ali talking to?'

b. *ki Ali bâ <ki> harf mizad

who Ali with speech hit.3SG

11) ali bâ kesi harf mizad, vali nemidunam *(bâ) ki.

Ali with someone speech hit.3SG but NEG-know.1SG with who

'Ali was talking to someone, but I don't know who.' (Toosarvandani, 2011)

Merchant (2001) finds this correlation true for a large number of languages. As a matter of fact, if a language shows preposition stranding in non-elliptical structures, it will show preposition stranding under sluicing. According to Abels (2003) prepositional phrases have a special requirement that forces any extraction out of them to proceed through Spec PP. The ban on prepositions in Persian conflicts with the requirement that movement must at least across a full phrase category so the complement of the preposition should move through Spec PP. The conflict is solved if preposition stranding does not occur and the preposition is pied-piped under wh-movement.

Toosarvandani proposes that sluicing in Persian is derived by movement of an interrogative phrase to the Spec of a focus projection; then the sister of F, TP, is deleted (at PF) (12). The proposal is schematized in (13).

12) parvin ye jâi raft. Nemidunam [FP kojâ [ Parvin $<$ kojâs raft.]]

Parvin one place went.3SG. NEG.know.1SG where Parvin <where> went.3SG

'Parvin went somewhere. I don't know where.'

13)

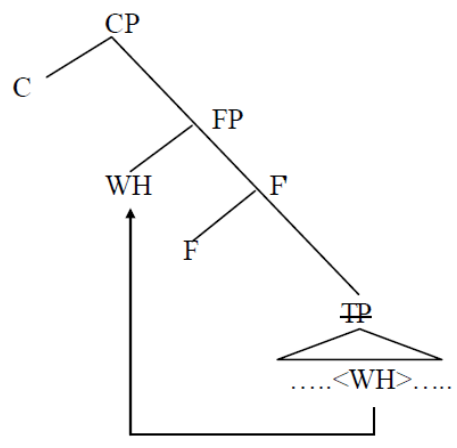

The first syntactic evidence that the remnant in Persian sluicing is in Spec FP comes from the behavior of complementizers in Persian. The focus phrase is located above TP but below CP. The complementizer ke can appear in a sluice and TP is deleted so there should be another node, Spec FP, on which the remnant is located.

14) midunam ke Ârash ye ketâbi xund vali nemidunam ke chi.

Know.1SG that Ârash one book read.3SG but NEG.know.1SG that what

ketâb-i-o Ârash 〈che ketâb-i-o> xund.

bokk.IND.OBJ Ârash read.3SG

'I know that Ârash read a book, but I don't know what book he read.'

15) vali nemidunam ke......

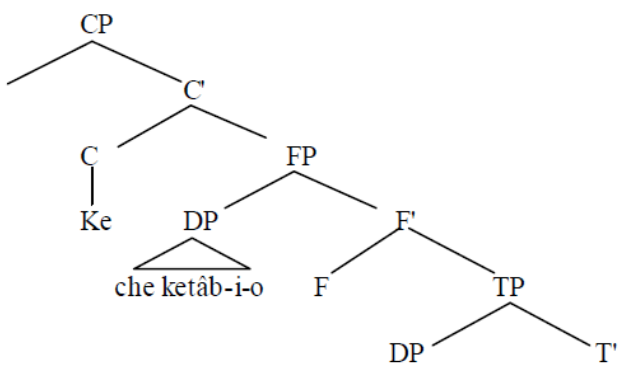

The presence of the complementizer in sluicing is counter to the SLUICING-COMP-GENERALIZATION in which no non-operator material may appear in COMP in sluicing (Merchant, 2001). This generalization holds only when the remnant of the sluice is in Spec CP as in English, the generalization does not hold in Persian; therefore, interrogative phrases raise to Spec FP.

In sum, interrogative phrases undergo the same information-structure-driven movement processes that noninterrogative phrases do. Focus fronting is responsible for moving the remnant out of the deleted constituent in Persian 
sluicing to a position where it can be stranded. Consequently, when an interrogative phrase raises to Spec FP, it must stand in a contrastive relationship with another phrase of the same type.

\section{MultiPle SLUICING}

In languages such as Persian, Japanese and Bulgarian where multiple wh-fronting is possible, multiple sluicing is acceptable. Multiple sluicing can be simply defined as construction with two or more remnants. Nishigauchi (1998) believes that this construction involves a multiple occurrence of wh-phrases in Spec CP, and that an LF Copying analysis is well-motivated and necessary.

16) a. john-ga. [dareka-ga nanika-o katta to] it-ta.

John-Nom someone-Nom something-Ace bought that said

'John said someone bought something.'

b. mary-wa [dare-ga nani-o ka] siri-tagat-te iru.

Mary-Top who-Nom what-Acc Q know-want is

'lit. Mary wants to know who what.' Japanese (Takahashi, 1994)

17) ye kasi be pedar ye chizi goft.

One person to father one thing said.3SG

'Somebody said something to the father.'

vali nemidunam (ayâ/yani/ $\varnothing)$ ki chi-o.

but NEG.know.1SG (Q marker) who what-CASE

'lit. but I don't know who what.' Persian

Takahashi argues that in a sentence like (16.b) two wh-phrases are adjoined to each other in Spec CP and they are licensed by the $\mathrm{C}$ head which dominates the $\mathrm{Q}$ marker $k a$, with TP being deleted.

English is anon-multiple wh-fronting so we expect English not to allow multiple sluicing. Takahashi (1994) asserts that in English only one wh-phrase can appear as the remnant.

18) *Someone bought something, I don't know who what.

Example (18) is ungrammatical; however, we find sentences like (19 and 20) that are acceptable:

19) I know that in each instance one of the girls got something from one of the boys. ? But which from which. Bolinger (1978)

20) I know that in each instance one of the girls got something from one of the boys. ? But they didn't tell me which fro which. Nishigauchi (1998)

21) I know that in each instance one of the girls got something from one of the ys. * But they didn't tell me which fro which got. Bolinger (1978)

Nishigauchi (1998) does not consider these as genuine examples of 'multiple sluicing' in English, that is they are not cases of ellipsis involving multiple occurrences of wh in Spec CP in a pre-spell-out representation. Rather, they are similar to Gapping in that one wh occupies a non-CP position while the other wh presumably is in Spec CP. By contrast, Richards $(1997,2001)$ argues that some of the non-interpretable features on CP driving wh-movement are weak. It drives movement out of what will become an elliptical site. In this case PF only has to consider a single position for pronunciation (the head of the chain), since nothing in the ellipsis site will be pronounced. If the TP containing the trace is not deleted like (21), the defective feature is present at the PF interface, so the derivation crashes.

Takahashi considers the ECP to analyze the multiple sluicing and proposes that it involves clause mate restriction among wh-phrases ,i.e. the wh-phrases must originate in the same clause prior to deletion. The lower wh adjoined to the higher wh formulates an amalgamated wh unit that subsequently moves to Spec CP.

22)

a. $[\mathrm{CP}[\mathrm{IP} \ldots . . \mathrm{wh} 1 \ldots \mathrm{wh} 2 \ldots]]$

b. $[\mathrm{CP}[\mathrm{IP} \ldots$ wh $2-[$ wh1 1$]] \ldots . . . \mathrm{t} 2 \ldots]]$

There cannot be a clause bounding between the two whs. Since it forms a barrio to A-movement, crossing CP, the movement is illicit.

23)

$[\mathrm{CP}[\mathrm{IP} \ldots \ldots \mathrm{wh} 2-[\mathrm{wh} 1]] \ldots[\mathrm{CP} \ldots \mathrm{t} 2 \ldots]]$

Nishigauchi (1998)

\section{Syntax of Wh-Fronting In Persian AND Multiple SLuicing}

To shed lights on multiple sluicing in Persian, we prefer to look into the phenomenon of wh-fronting. Persian as a pro drop, wh-in-situe language allows multiple wh-fronting that is not obligatory and occurs for the sake of focusing. In Persian, wh phrases do not need to move overtly from the position in which it is base-generated, but due to focusing discourse-related reasons, wh-fronting is possible. Multiple wh questions in Persian, like Japanese, should involve 
either a single-pair or a pair-list interpretation (Bošković, 1998). However, according to Lotfi (2003) Persian seems to pattern with English rather than Japanese and seems to have only pair-list interpretations in multiple wh questions.

There can be a correlation between multiple sluicing and pair-list interpretation. The failure of multiple sluicing correlates with the failure of pair-list interpretation in multiple wh question. However, the presence of pair-list interpretation is not enough for multiple sluicing.

In English wh-phrase should raise to CP to fulfill feature checking. This overt movement is obligatory because whfeature is strong. A strong feature has two properties: it triggers an overt operation before spell-out, i.e. overt movement and it induces cyclicity, i.e. a strong feature cannot be passed by $\alpha$ that should satisfy it and later checking by $\beta$. In multiple wh questions, when a wh-phrase which is closer to C is attracted and [wh] and [EPP] features are checked and deleted, there is no need for the other wh-phrase to move. The landing site is already occupied and the movement is not economical. If it moves, the derivation will crash.

24) They met Ali there.

[сР who did [тр they meet where?]]

*Who where did they meet?

25) [ср[тр Âram chi goft?]]

Âram what siad.3SG

'What did Âram say?'

26) [ст[тр chi Âram $t_{1}$ goft?]] what Âram siad.3SG

'What did Âram say?'

27) nemidunam ke ki-o Ali did?

NEG.know.1SG that who.OBJ Ali saw.3SG

*'I don't know that who Ali saw.'

In (25) <chi> remains in situe and wh feature is attracted into CP covertly. We cannot say in (26) <chi> moves to CP covertly; wh feature cannot be weak sometimes moving overtly and some other time moving covertly as a strong feature. Lotfi (2003) also argues that wh phrases in Persian move to focus phrase not CP and it is a pragmatic requirement rather than a morphological one. In other words, Persian wh-phrase can optionally move to a focus position in the left periphery at spec, FP for emphasis, but there is no "wh-movement" to spec, CP (Kahnemuyipour, 2001). On the other hand, we can use complementizer $k e$ and the remnant $k i$ together (27). In Persian wh feature is still noninterpretable but weak; therefore, we cannot attract wh-phrase and movement will be covert so it moves to focus phrase. (Examples taken from Lotfi 2003)

Persian multiple wh-fronting, despite its problems called riddles by Lotfi, can explain multiple sluicing. For instance, as shown in (28) and (29), the accusative case of the object wh-phrase shown by direct object particle râ (cliticized as ro/-o) makes certain superiority violations possible. Since in Persian wh phrases move to focus phrase and the motivation is pragmatic, we can move as many as wh words a we want; it, however, has "mysterious" restrictions that are problematic in multiple sluicing too. In Persian, using conjunctions and between two wh phrases is also favorable. (See the examples)

28) Âram kojâ chi xarid?

Âram where what bought.3SG

'where did Âram bought what?'

29) a. *Âram chi kojâ xarid?

b. Âram chi-o kojâ xarid?

30) a. ki kojâ chi xarid?

Who where what bought.3SG

Intended:' who bought what where?'

b. *ki chi kojâ xarid?

c. ki chi-o kojâ xarid?

d. Chi ki kojâ xarid?

e. Chi-o ki koja xarid?

31) a. Ali ye jâi ye chizi xarid vali nemidunam kojâ chi. Ali one place one thng bought.3SG but NEG.knoe.1SG where what

'Ali bought something somewhere, but I don't know where what.'

b. Ali ye jâi ye chizi xarid vali nemidunam chi-o kojâ.

c. *Ali ye jâi ye chizi xarid vali nemidunam chi kojâ.

d. .... vali nemidunam chi va kojâ

.... but NEG.know.1SG what and where

'.... but I don't know what and where.'

32) a. Ye nafar ye chizi ye jâi xarid vali nemidunam ki kojâ chi One person one thing one place bought.3SG but NEG.know.1SG who where what 'Someone bought something somewhere, but I don't know who where what.' 
b. ....* vali nemidunak ki chi kojâ

c. ....vali nemidunam ki chi-o kojâ

d. ...*vali nemidunam chi ki kojâ

e. ....vali nemidunam chi-o ki kojâ xarid

f. .... vali nemidunam ki va kojâ va chi

.... but NEG.know.1SG who and where and what

.... 'But I don't know who and where and what.'

Persian allows non-d-linked words (Pesetesky, 1987) as remnants (33). In English the non-d-linked wh words, referred to as wh the hell phrases by Den Dikken and Giannakidou (2002), are considered negative polarity items that cannot act as remnants and cannot occur in situ and do not support non echo readings when occurring in root multiple questions. In spite of this, Toosarvandani (2008) argues that Persian allows only wh remnants. He believes that some of the tests proposed by Merchant (2001) to distinguish pseudosluicing from real sluicing are not applicable to Persian. Accordingly, aggressively non-D-linked wh-phrases occurring as the pivot in a cleft (see example 34 taken from Toosarvandani, 2008) but not the remnant in a sluice do not exist. He concludes that Persian does not have swiping (see example 35 taken from Merchant, 2001) as well, the phenomenon in which a wh-word inverts with a preposition under sluicing. However, as our informants accepted sentences (36) and (37) with non-wh-phrase remnants as well-formed structures.

33) ye jâi rafte bud, mixâm bedunam kodum jahanami

One place went.3SG want.1SG know.1SG where hell

'He went somewhere, I want to know where-the-hell.'

34) Who the hell was it (that left the door open)?

35) Bees are getting into the house, but we can't figure out where from.

36) sârâ be yeki qarâr mizâre vali fekr nemikonam bâ Ali

Sara with someone date make.3SG but thought NEG.make.1SG with Ali

'Sara dates someone, but I don't thing with Ali.

37) mixâd mâshin bexare vali fekr nemikonam be in zudiyâ

Want.3SG car buy.3SG but thought NEG.make.1SG to this soon

'He wants to buy a car, but I don't think that soon.'

Consequently, there might be non-interrogative sluicing in Persian. Furthermore, based on our analyses, we can have non-d-linked wh words in Persian as well. As this argument requires widely accepted tenets of grammatical analysis, we rather discuss it in another paper after collecting more data to support our proposal.

\section{Conclusion}

It can be concluded that sluicing as ellipsis of the sentential complement to an interrogative complementizer hosting a wh phrase describes the connection between certain types of constituents and kinds of interpretation associated with those strings. Despite differences worth considering, this syntactic configuration is similar in Persian and English in some respect. The implication of our arguments is that focus fronting is responsible for moving the remnant of the deleted constituent in Persian sluicing to a position where it can be stranded. The possibility of wh fronting in Persian and its problematic nature with all restrictions could help us explain the phenomenon of sluicing. Besides, sluicing is not simply the by-product of syntax in a language, but it has a syntax of its own. It also suggested that looking outside the domain of syntax, we can put sluicing into further investigations from semantic and pragmatic perspectives. Definitely these analyzed examples and proposed ideas could shed light on some but not all of the relevant facts. They aim to pave the way for further research about swiping and wh the hell phrases that have remained one of the most mysterious syntactic aspects in the sluicing arena in Persian.

\section{REFERENCES}

[1] Abels, K. (2003). Successive cyclicity, anti-locality, and adposition stranding. Ph.D. dissertation, University of Connecticut.

[2] Boeckx, C. (2006). Bare Syntax. Ms. dissertation, Harvard University.

[3] Bolinger, D. (1978). Asking more than one thing at a time. In H. Hiz, (ed.), Questions. Dordrecht, Reidel, 107-150.

[4] Bošković, Ž. (1998). Multiple wh-fronting and economy of derivation. In Proceedings of the West Coast Conference on Formal Linguistics 16. Stanford University, Stanford, California, 49-63.

[5] Den Dikken, M. \& Giannakidou, A. (2002). From Hell to polarity: “Aggressively non-D-linked” wh-phrases as polarity items. Linguistic Inquiry 33.1, 31-61.

[6] Kahnemuyipour, A. (2001). On wh-questions in Persian. Canadian Journal of Linguistics/Revue canadienne de linguistique 46. $1 / 2,41-61$.

[7] Lasnik, H. (2005). Review of Jason Merchant: The syntax of silence. Language, 81, 259-265.

[8] Lobeck, A. (1995). Ellipsis: functional heads, licensing and identification. Oxford: Oxford University Press.

[9] Lotfi, A.R. (2003). Persian wh-riddles. In C. Boeckx and K. K. Grohmann (eds.), Multiple wh-fronting. Amsterdam/ Philadelphia, John Benjamins Publishing Company, 61-186.

[10] Ludlow, P. (2005). A note on alleged cases of non-sentential speech. In R. Eluguardo and R. Stainton (Eds.), Non-sentential speech. Dordrecht: Kluwer. 
[11] Merchant, J. (2001). The syntax of silence: sluicing, islands, and the theory of ellipsis. Oxford: Oxford University Press.

[12] Merchant, J. (2008). Variable island repair under ellipsis. In K. Johnson (ed.), Topics in ellipsis. Cambridge University Press: Cambridge, 132-153.

[13] Nishigauchi, T. (1998). Multiple sluicing in Japanese and the functional nature of wh phrases. Journal of East Asian Linguistics, 7, 121-152.

[14] Pesetsky, D. (1987). WH-in-situ: movement and unselective binding. In E. Reuland and A.G.B. terMeulen (eds.), The linguistic representation of (in)definiteness. MIT Press, Cambridge, MA, 98-129.

[15] Richards, N. (1997). What moves where when in which language? PhD dissertation, MIT.

[16] Richards, N. (2001). Movement in language. Oxford: Oxford University Press.

[17] Ross, J.R.(1969). Guess who? In Robert I. Binnick, Alice Davison, Georgia M. Green, Jerry, L. Morgan et. al. (eds.), Proceedings of the Fifth Regional Meeting of the Chicago Linguistic Society. Chicago Linguistic Society, University of Chicago, Chicago, Illinois, 252-286.

[18] Takahashi, D. (1994). Sluicing in Japanese. Journal of East Asian Linguistics 3, 265-300.

[19] Toosarvandani, M.( 2008). Wh-movement and the syntax of sluicing. Journal of Linguistics, 44, 677-722.

[20] Toosarvandani, M. (2011). Ellipsis in crosslinguistic perspective, sluicing in English. http://toosarva.scripts.mit.edu/teaching/2011-winter/ling-252/handout-02-09.pdf (accessed 20/9/2011).

Saeedeh Shafiee Nahrkhalaji was born in Isfahan, Iran in 1981. She received her B.A. in Translation Studies and her M.A. in TEFL from Islamic Azad University of Khorasgan (Isfahan). She is a PhD candidate in TEFL at Islamic Azad University of Khorasgan (Isfahan) and a faculty member with the rank of Lecturer at Islamic Azad University of Najafabad where she teaches courses of Linguistics, Theories of Second Language Acquisition, Error Analysis and Research in Applied Linguistics. Her current research interests include Interlanguage Studies, Cultural Studies and Bilingualism.

Morteza Rashidi Ashjerdi was born in Ashjerd, Isfahan, Iran, in 1973. He received his BA in Persian Language and Literature from Isfahan University (1995) and his MA from Teacher Training University of Tehran (1998). He completed his PhD in Isfahan University in 2008. He is an Associate Professor in the Department of Persian Language and Literature at Islamic Azad University of Najafabad and a Lecturer at Isfahan University, Iran. He has been working as the head of the department for 3 years as well.

His research interests lie in the area of Persian culture studies, literary stylistics, contemporary literature studies and literary criticism. He has published five books in his field and authored some articles. He served on over different conference and workshop program committees and editorial board of journals. He has supervised and advised many MA dissertations in different universities as well and has given speeches as the keynote speaker in related conferences. 